American Journal of Pharmacology and Toxicology 4 (4): 118-126, 2009

ISSN 1557-4962

(C) 2009 Science Publications

\title{
Studies on Wound Healing and Antiulcer Activities of Extract of Aerial Parts of Phyllanthus niruri L. (Euphorbiaceae)
}

\author{
${ }^{1}$ C.O. Okoli, ${ }^{1}$ A.C. Ezike, ${ }^{1}$ P.A. Akah, ${ }^{2}$ S.O. Udegbunam, ${ }^{1}$ T.C. Okoye, \\ ${ }^{1}$ T.P. Mbanu and ${ }^{1}$ E. Ugwu \\ ${ }^{1}$ Department of Pharmacology and Toxicology, Faculty of Pharmaceutical Sciences, \\ University of Nigeria, Nsukka 410001, Enugu State, Nigeria \\ ${ }^{2}$ Department of Veterinary Surgery, Faculty of Veterinary Medicine, \\ University of Nigeria, Nsukka 410001, Enugu State, Nigeria
}

\begin{abstract}
Problem statement: Phyllanthus niruri is widely used in many parts of the world to manage a wide range of diseases. As part of efforts to elucidate its pharmacological activities and hence medicinal potential, we studied the wound healing and antiulcer properties of extract of the aerial parts using experimentally-created wounds and ulcers in rodents. Approach: Wound healing effect was assessed using excision and dead space wound models while antiulcer activity was evaluated using indomethacin-, ethanol acid- and cold-restraint stress-induced ulcer models. Results: The extract $(5,10 \%)$ significantly $(\mathrm{p}<0.05)$ reduced the wound diameter producing 90.9 and $93.7 \%$ wound contraction respectively on day 18 post wounding. It also reduced epithelialization time of excised wounds and increased the rate of wound closure, with $\mathrm{WC}_{50}$ of $8.7 \%$. The extract $(400 \mathrm{mg}$ $\mathrm{kg}^{-1}$ ) also significantly $(\mathrm{p}<0.05)$ increased the weight of granuloma tissue. In antiulcer studies, the extract significantly $(\mathrm{p}<0.05)$ inhibited the development of ulcers induced by indomethacin and moderately inhibited ethanol acid-induced ulcer. It was, however, devoid of any such effect in coldrestraint stress-induced lesions at the doses used. Phytochemical analysis of the extract revealed the presence of alkaloids, saponins, tannins, flavonoids, reducing sugar, carbohydrates and glycosides. Conclusion: These findings indicate that constituents of aerial parts of $P$. niruri possess wound healing and antiulcer properties.
\end{abstract}

Key words: Wound healing, antiulcer, Phyllanthus niruri

\section{INTRODUCTION}

Phyllanthus niruri L. (Euphorbiaceae) is an annual and field weed widespread in temperate and tropical climates $^{[1]}$. The morphology of the plant has been described $^{[2]}$. It is popularly used in Asia, Africa and South America ${ }^{[3]}$ as a stomachic, aperitive, antispasmodic, anti-hepatotoxic, antiviral, antibacterial, laxative, diuretic, carminative, in the management of diabetes, constipation, fever including malaria, jaundice, hepatitis B, dysentery, gonorrhea, syphilis, tuberculosis, cough, influenza, diarrhea, vaginitis, tumors, kidney stones ${ }^{[4-9]}$. Studies on extracts from various parts of the plant have revealed the antioxidant $^{[10]}$ and nitric oxide scavenging ${ }^{[11]}$, antimalarial (antiplasmodial) ${ }^{[12-17]}$, antihyperuricemic ${ }^{[18]}$ analgesic ${ }^{[19,20]}$, diuretic, hypotensive, hypoglycemic ${ }^{[21]}$, hepatoprotective ${ }^{[4,22-27]}$ hepatocurative $^{[10]}$ hypolipemic ${ }^{[28]}$, nematicidal ${ }^{[29]}$, platelet aggregation inhibitory ${ }^{[30]}$, nephrolithiatic ${ }^{[31]}$, HIV-1 reverse transcriptase inhibitory ${ }^{[23]}$ HIV replication inhibitory ${ }^{[33]}$, HIV/RRE binding inhibitory $^{[34]}$, urolithiatic ${ }^{[35-40]}$ and vasorelaxant ${ }^{[1]}$ activities.

Several phytochemical constituents of this plant have been isolated and some were shown to be pharmacologically active. These include the alkaloids4-methoxy-securinine (Phyllanthine) and 4-methoxynor-securinine ${ }^{[41]}$, arabinogalactan which stimulates superoxide anion production ${ }^{[3,42]}$, ellagic acid, brevifolin carboxylic acid and ethyl brevifolin carboxylate with aldose reductase inhibitory effect ${ }^{[43]}$, 1-O-galloyl-6-O-luteoyl-alpha-d-glucose with antibabesial and antiplasmodial activities, beta-glucogallin,

Corresponding Author: A.C. Ezike, Department of Pharmacology and Toxicology, Faculty of Pharmaceutical Sciences, University of Nigeria, Nsukka 410001, Enugu State, Nigeria Tel: 2340852820538 
quercetin 3-O-beta-d-glucopyranosyl-(2-1)-O-beta-dxylopyranoside, beta sitosterol, gallic acid ${ }^{[16]}$, the lignans- phyllanthin, hypophyllanthin, phyltetralin with antihyperuricemic $^{[18]}$ and antihepatotoxic effects ${ }^{[4]}$, cubebin dimethyl ether, urinatetralin ${ }^{[44]}$, niranthin ${ }^{[45]}$, methyl brevifolincarboxylate with vasorelaxant ${ }^{[1]}$ and platelet aggregation inhibitory ${ }^{[30]}$ effects, niruriside with HIV/RRE binding inhibitory effect ${ }^{[34]}$, the prenylated flavanones- 8-(3-Methyl-but-2-enyl)-2-phenylchroman4-one and 2-(4-hydroxyphenyl)-8-(3-methyl-but-2enyl)-chroman-4-one with nematicidal activity ${ }^{[29]}$, triacontanal and tricontanol with antihepatotoxic effect $^{[4]}$ and xylans ${ }^{[3]}$.

In continuation of efforts to elucidate the pharmacological activities and hence medicinal potential of this plant, we studied the wound healing and antiulcer properties of extract of the aerial parts using experimentally created wounds and ulcers in rodents.

\section{MATERIALS AND METHODS}

Animals: Adult albino rats (150-200 g) of either sex obtained from the Department of Pharmacology and Toxicology, University of Nigeria Nsukka were used. The animals were housed in metal cages and maintained on standard pelleted rodent diet and water ad libitum. All animal experiments were in compliance with the National Institute of Health Guide for Care and Use of Laboratory Animals (Pub No. 85-23, revised 1985).

Drugs: Neomycin-bacitracin powder $\left(\right.$ Cicatrin $\left.^{(\mathrm{R})}\right)$.

Reagents: Chloroform, methanol, dimethylsulfoxide (DMSO), ethanol.

Preparation and extraction of plant material: Fresh whole $P$. niruri plants were collected from Orba, Enugu State in May 2008 and authenticated by Mr. Alfred Ozioko of the International Centre for Ethnomedicine and Drug Development (InterCEDD) Nsukka, Nigeria. The plants were thoroughly cleaned and the aerial parts cut into smaller pieces, sun-dried for 7 days and milled to coarse powder using a mechanical grinder. The powdered plant material $(2 \mathrm{~kg}$ ) was extracted with methanol by continuous extraction in a soxhlet. Concentration of the extract in a rotary evaporator under reduced pressure afforded $140.6 \mathrm{~g}$ of the methanol extract (ME; 7.03\% w/w). Phytochemical analysis for identification of constituents using conventional methods ${ }^{[46,47]}$ gave positive reactions for alkaloids, saponins, carbohydrates, reducing sugar, flavonoids, steroids, terpenoids, tannins, resins and glycosides.

Wound healing activity studies: The effect of ME on wound healing was studied in rodents using experimentally-created excision and dead space wounds.

Excision wound: Animals randomly placed into four groups (I-IV; $\mathrm{n}=6)$ were anaesthetized with chloroform and excision wounds $(2.5 \mathrm{~cm}$ diameter $)$ created on the depilated dorsal thoracic region ${ }^{[48]}$. Groups I and II received ME (5 or 10\%) ointment while III and IV were treated with neomycin-bacitracin $(5 \%)$ or vehicle (ointment base) respectively. The ointments were topically applied once daily from day 1, after wound creation and continued until the wound healed. The wound diameter was measured on alternate days and the epithelialization period recorded at the end of the study. Wound contraction (\%) was calculated using the relation:

Wound contraction $(\%)=\left[\left(\mathrm{W}_{\mathrm{D} 0}-\mathrm{W}_{\mathrm{Dt}}\right) / \mathrm{W}_{\mathrm{D} 0}\right] 100$

Where:

$\mathrm{W}_{\mathrm{D} 0}=$ The wound diameter on day zero

$\mathrm{W}_{\mathrm{Dt}}=$ The wound diameter on day $\mathrm{t}$

The time taken for $50 \%$ of wound closure $\left(\mathrm{WC}_{50}\right)$ was read off a plot of wound closure (\%) against time (days).

Dead space wound: Dead space wounds were created by making a pouch through a small cut and implanting sterile cotton pellets (50 $\mathrm{mg}$ each) on either side of the axilla on the ventral surface of each rat. The animals were randomly divided into three groups $(n=6)$. Groups I and II received 200 or $400 \mathrm{mg} \mathrm{kg}^{-1}$ of ME suspended in DMSO (10\%) respectively. Group III served as control and received the vehicle. Extract administration was done orally once a day from day 09. On day 10 , the animals were sacrificed by overdose of chloroform anaesthesia and the pellets carefully removed and dried in an oven at $60^{\circ} \mathrm{C}$ to a constant weight and the weight recorded. The level of increase (\%) in the weight of granuloma tissue formed was calculated relative to the control.

Antiulcer activity studies: The ulcer-healing or protective effect of the extract was studied in rodents using ulcers induced by different ulcerogens.

Indomethacin-induced ulcers: Animals were fasted for $18 \mathrm{~h}$ but allowed access to water only prior to the 
experiment and divided into 4 groups $(n=6)$. Groups I and II received 200 or $400 \mathrm{mg} \mathrm{kg}^{-1}$ of ME, while III and IV received cimetidine $\left(32 \mathrm{mg} \mathrm{kg}^{-1}\right)$ or the vehicle (10\% v/v DMSO) respectively. Thirty minutes after oral administration of extract, ulcer was induced by oral administration of indomethacin $\left(20 \mathrm{mg} \mathrm{kg}^{-1}\right)$. After $7 \mathrm{~h}$, the animals were scarified and the abdomen opened. The stomach was isolated and opened along the greater curvature and rinsed under a stream of water. Lesions on the gastric mucosa were observed with a hand lens $(\mathrm{x} 10)^{[49]}$ and scored 0-4 using an arbitrary scale where $0=$ no lesions; $0.5=$ hyperemia; $1=$ one or two lesions; 2 = severe lesions; $3=$ very severe lesions and $4=$ mucosa full of lesions ${ }^{[50]}$.

Ethanol-acid induced ulcers: Animals were fasted, grouped and treated as above. Thirty minutes after oral administration of ME, ulcer was induced with oral administration of ethanol-acid $\left(25 \mathrm{~mL} \mathrm{~kg}^{-1}\right.$ of $0.3 \mathrm{M} \mathrm{HCl}$ in $60 \%$ ethanol ${ }^{[51]}$. One hour later, the animals were sacrificed and their stomachs removed and cut along the greater curvature. The open stomach was rinsed in a stream of water and the lesions on the gastric mucosa observed and scored as described above.

Cold-restraint stress-induced ulcer: Acute, gastric lesions were induced by stress according to a modified method of Nagura and Bacchi ${ }^{[52,53]}$. Animals were fasted for $18 \mathrm{~h}$, grouped and treated as above. Thirty minutes after oral administration of ME, ulcer was induced by immobilizing the animals in cylindrical cages vertically placed in bowls containing water to the level of the xiphoid process. The bowls were kept in a refrigerator maintained at $19^{\circ} \mathrm{C}$. After $17 \mathrm{~h}$, the animals were sacrificed by overdose of chloroform anaesthesia and their stomachs removed and opened along the greater curvature. The stomach was rinsed in a stream of water and the ulcer lesions observed and scored as described above.
Statistical analysis: The data obtained was analyzed using One-way analysis of variance (ANOVA) and further subjected to LSD post hoc test for multiple comparisons. The results were presented as Mean \pm SEM. Differences between means was accepted significant at $\mathrm{p}<0.05$.

\section{RESULTS}

Effect of ME on excision wound: Topical application of ME caused a significant $(\mathrm{p}<0.05)$ concentrationrelated reduction in wound diameter (Table 1$)$. The ME also significantly $(\mathrm{p}<0.05)$ reduced the epithelialization period of excision wounds (Table 2). On day 18, ME-treated rats showed $93.7 \%$ wound contraction compared to control rats $(84.2 \%)$. The $\mathrm{WC}_{50}$ values showed that $\mathrm{ME}(10 \%)$ produced a better wound closure rate ( 8.7 days) than cicatrin (9.0 days) (Fig. 1).

Effect of ME on dead space wound: In the dead space wound model, oral administration of ME caused a significant $(\mathrm{p}<0.05)$ and dose-related increase in the weight of granuloma tissue (Table 3 ).

Effect of ME on indomethacin-induced ulcer: The ME significantly $(p<0.05)$ inhibited the development of indomethacin-induced ulcer in a dose-related manner. The effect of the higher dose was comparable to that of cimetidine (Table 4).

Effect of ME on ethanol acid-induced ulcer: The ME (400 $\mathrm{mg} \mathrm{kg}^{-1}$ ) moderately inhibited the development of ulcers induced by ethanol acid (Table 4).

Effect of ME on cold-restraint stress-induced ulcer: Pretreatment with ME did not prevent the development of ulcers induced by cold restraint stress (Table 4).

Table 1: Effect of extract on diameter of excision wounds in rats

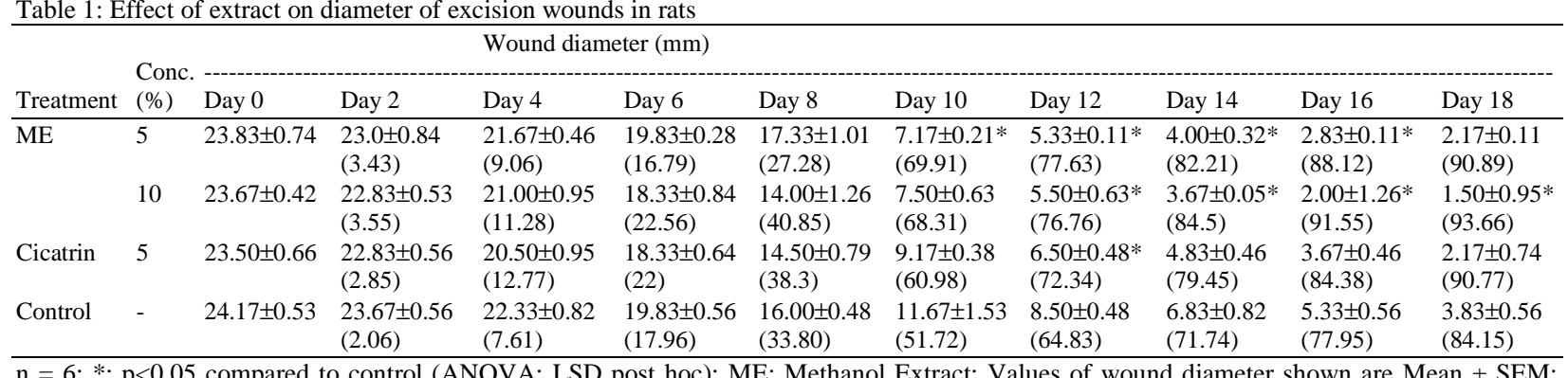

Values in parenthesis represent wound closure $(\%)$; LSD post hoc); ME: Methanol Extract; Values of 
Am. J. Pharm. \& Toxicol., 4 (4): 118-126, 2009

Table 2: Effect of extract on epithelialization period of excision wounds in rats

\begin{tabular}{|c|c|c|c|}
\hline Treatment & Conc. (\%) & $\begin{array}{l}\text { Epithelialization } \\
\text { period (Days) }\end{array}$ & Reduction (\%) \\
\hline \multirow[t]{2}{*}{$\mathrm{ME}$} & 5 & $20.0 \pm 0.0$ & 14.27 \\
\hline & 10 & $17.0 \pm 1.26 *$ & 27.13 \\
\hline Cicatrin & 5 & $19.3 \pm 0.42 *$ & 17.15 \\
\hline Control & - & $23.3 \pm 0.84$ & - \\
\hline
\end{tabular}

Table 3: Effect of extract on granulation tissue formation in rats

\begin{tabular}{llll}
\hline Extract & $\begin{array}{l}\text { Dose } \\
\left(\mathrm{mg} \mathrm{kg}^{-1}\right)\end{array}$ & $\begin{array}{l}\text { Weight of granuloma } \\
\text { tissue }(\mathrm{mg})\end{array}$ & $\begin{array}{l}\text { Increase in } \\
\text { granuloma tissue }(\%)\end{array}$ \\
\hline ME & 200 & $211.83 \pm 6.03$ & 10.43 \\
& 400 & $386.17 \pm 28.96^{*}$ & 101.70 \\
Control & - & $191.83 \pm 18.71$ & -
\end{tabular}

$\mathrm{n}=6$; *: $\mathrm{p}<0.05$ compared to Control (ANOVA; LSD post hoc); ME: Methanol Extract; Values of granuloma tissue weight are Mean \pm SEM; Increase in granuloma tissue was calculated relative to the control

Table 4: Effect of extract on ulcers induced by various agents in rats

\begin{tabular}{lllll}
\hline & & \multicolumn{3}{c}{ Ulcer scores } \\
Treatment & $\begin{array}{l}\text { Dose } \\
\left(\mathrm{mg} \mathrm{kg}^{-1}\right)\end{array}$ & $\begin{array}{l}\text { Indomethacin } \\
\text { ulcer }\end{array}$ & $\begin{array}{l}\text { Ethanol- } \\
\text { acid ulcer }\end{array}$ & $\begin{array}{l}\text { Cold restraint } \\
\text { stress ulcer }\end{array}$ \\
\hline ME & 200 & $2.50 \pm 0.66$ & $0.67 \pm 0.11$ & $2.83 \pm 0.74$ \\
& & $(16.67)$ & $(\mathrm{NI})$ & $(\mathrm{NI})$ \\
& 400 & $0.83 \pm 0.11^{*}$ & $0.50 \pm 0.0$ & $2.67 \pm 0.42$ \\
& & $(72.33)$ & $(25.37)$ & $(\mathrm{NI})$ \\
Cimetidine & 32 & $0.67 \pm 0.11^{*}$ & $0.17 \pm 0.11 *$ & $2.33 \pm 0.21$ \\
& & $(77.67)$ & $(70.15)$ & $(\mathrm{NI})$ \\
Control & - & $3.00 \pm 0.37$ & $0.67 \pm 0.11$ & $2.33 \pm 0.56$ \\
\hline
\end{tabular}

$\mathrm{n}=6$; *p $<0.05$ compared to Control (ANOVA; LSD post hoc); ME: Methanol Extract; Ulcer scores shown are Mean \pm SEM; The ulcer lesions were scored $0-4$ where $0=$ no lesions; $0.5=$ hyperemia; $1=$ one or two lesions; $2=$ severe lesions; $3=$ very severe lesions and $4=$ mucosa full of lesions; Values in parenthesis represent ulcer inhibition (\%) calculated relative to control

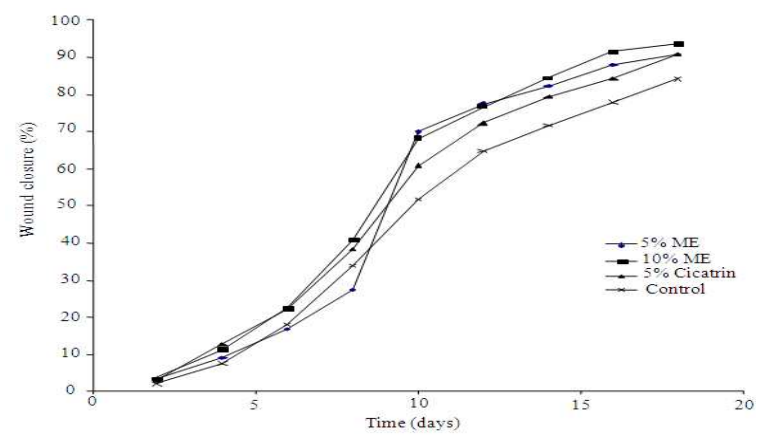

Fig.1: Effect of extract on wound closure

\section{DISCUSSION}

Wounds occur when the continuity of the skin or mucous membrane is broken ${ }^{[54]}$. On the other hand, peptic ulcers, are benign lesions of gastric or duodenal mucosa which result from a shift in the balance between the aggressive (acid, pepsin, H. pylori) and protective (gastric mucus and bicarbonate secretion, prostaglandins) mechanisms. While wounds occur under acute conditions and are healed through a natural process that may be prolonged without treatment, peptic ulcers are amplified and sustained by their pathophysiological mechanisms. Whatever is the basic amplification mechanism of the disease process; treatment with wound-healing or anti-ulcer agents respectively stimulates or accelerates healing.

Experimental assessment of the wound healing and antiulcer activities of $P$. niruri extract showed increased rate of wound contraction and epithelialization, increased granuloma tissue formation and protection of the gastric mucosa from ulcerogenic effects of indomethacin and ethanol-acid in treated animals. Chronic topical application of the extract on excision wounds accelerated wound contraction and reduced epithelialization period in rats. Wound healing involves regeneration of specialized cells by proliferation of surviving cells and connective tissue response characterized by the formation of granulation tissue ${ }^{[55]}$. It is also characterized by haemostasis, reepithelialization and remodeling of the extracellular matrix. Epithelialization, which is the process of epithelial renewal after injury, involves the proliferation and migration of epithelial cells towards the centre of the wound while wound contraction is largely due to the action of myofibroblasts ${ }^{[56,57]}$. Thus, the effect of the extract on wound contraction and epithelialization suggest it may enhance epithelial cells migration and proliferation, as well as the formation, migration and action of myofibroblasts. On chronic oral administration, the extract enhanced granuloma tissue formation in dead space wounds. Granuloma tissue formed on an inert foreign body in a dead space comprises an accumulation of modified macrophages ${ }^{[55]}$ and histological giant cells and undifferentiated connective tissue consisting largely of collagen ${ }^{[55,57,58]}$. Increase in granuloma tissue, in dead space wound, is associated with enhanced collagen maturation and increased protein content as well as angiogenesis ${ }^{[59-61]}$ in the wound. These processes are indicators of new tissues generation and suggest that the extract may stimulate mechanisms associated with tissue regeneration. Closely related to this is the effect of growth factors secreted by macrophages on wounds. Macrophages secrete peptide growth factors that exert pro-healing effect by stimulating regeneration, fibroblast proliferation and activation and angiogenesis ${ }^{[55]}$. It is, therefore, likely that in addition to enhancing wound contraction and epithelialization, the 
extract may also stimulate processes associated with tissue regeneration.

In antiulcer studies, treatment with the extract protected rats from ulcers induced by indomethacin and ethanol-acid. These agents induce ulcers by different but related mechanisms that basically undermine gastric mucosal integrity and hence cytoprotection. Gastric mucosal damage caused by indomethacin and related non-steroidal anti-inflammatory drugs result from the inhibition of prostaglandins synthesis via the arachidonic pathway ${ }^{[62,63]}$. Prostaglandins serve protective functions in the stomach by maintaining gastric microcirculation ${ }^{[62,64]}$ and causing gastric secretion of bicarbonate ${ }^{[65]}$ and mucus ${ }^{[66]}$. Thus, the effect of the extract in this model suggests it may possess cytoprotective action probably by enhancing prostaglandins synthesis. The extract also mildly protected the gastric mucosa against ethanol-acid challenge. Ethanol-induced gastric mucosal lesions, predominant in the glandular part of the stomach, are caused by the direct toxic action of ethanol, reduction of the secretion of bicarbonate and depletion of gastric wall mucus ${ }^{[67,68]}$. Ethanol also reduces endogenous glutathione and prostaglandin levels, increases the release of histamine and influx of calcium ions ${ }^{[69]}$ and stimulates the synthesis of leukotriene $\mathrm{C}_{4}\left(\mathrm{LTC}_{4}\right)^{[70-72]}$ and oxygen free radicals ${ }^{[73]}$ thus causing increased lipid peroxidation which damages cells and cell membranes ${ }^{[74]}$. Agents that enhance mucosal defensive factors inhibit ethanol-induced gastric mucosal lesions $^{[75]}$. This is consistent with our earlier suggestion that the extract may owe its antiulcer effect to cytoprotection probably due to enhancement of prostaglandins synthesis. Although the precise mechanism of cytoprotection remains to be elucidated, the level of protection offered by the extract against indomethacin ulcers directly suggests it may enhance prostaglandins synthesis. This may be the reason for its ineffectiveness in protecting rats against cold-restraintstress ulcers where factors other than suppression of prostaglandin synthesis play major causative roles. Cold restraint ulcers are caused by factors such as increase in gastric motility and gastric acid secretion, decrease in $\mathrm{pH}^{[76]}$, vagal overactivity, mast cell degranulation, decrease in mucosal blood flow, gastric mucus and prostaglandins synthesis as well as generation of free radicals ${ }^{[77-81]}$. The extent of interaction of the extract with these mechanisms is not known, although the antioxidant ${ }^{[10]}$ and radical scavenging ${ }^{[11]}$ effects of this plant have been reported. Besides the likelihood of prostaglandin synthesis enhancement, it is unlikely that the extract interferes with any of the major processes responsible for ulcer induction in this model. As such, extract of aerial parts of this plant may not be effective in all cases of ulcer.

\section{CONCLUSION}

In conclusion, the results of this study indicate that aerial parts of $P$. niruri exhibit wound healing and antiulcer activities by accelerating wound closure and epithelialization and enhancing mucosal protection possibly by mobilization of endogenous prostaglandins. Although the extract may be effective in accelerating the healing of wounds, it may not be effective in all cases of ulcer.

\section{REFERENCES}

1. Iizuka, T., H. Moriyama and M. Nagai, 2006. Vasorelaxant effects of methyl brevifolincarboxylate from the leaves of Phyllanthus niruri. Biol. Pharm. Bull., 29: 177-179. http://www.ncbi.nlm.nih.gov/pubmed/16394535

2. Bagalkotkar, G., S.R. Sagineedu, M.S. Saad and J. Stanslas, 2006. Phytochemicals from Phyllanthus niruri Linn. and their pharmacological properties: A review. J. Pharm. Pharmacol., 58: 1559-1570. DOI: 10.1211/jpp.58.12.0001

3. Mellinger, C.G., E.R. Carbonero, G.R. Noleto, T.R. Cipriani and M.B. Oliveira et al., 2005. Chemical and biological properties of an arabinogalactan from Phyllanthus niruri. J. Nat. Prod., 68: 1479-83 http://www.ncbi.nlm.nih.gov/pubmed/16252911

4. Syamasundar, K.V., 1985. Antihepatoprotective principles of Phyllanthus niruri herbs. J. Ethnopharmacol., 14: 41-44. http://www.ncbi.nlm.nih.gov/pubmed/4087921

5. Olive-Bever, B., 1986. Medicinal Plants in Tropical West Africa. Cambridge University Press, Cambridge, ISBN: 052126815X, pp: 375.

6. Chopra, R.N., S.L. Nayar and I.C. Chopra, 1986. Glosssary of Indian Medicinal Plants. CSIR., Catholic Press, New Delhi, Ranchi, India. ISBN: 8172361262.

7. Unander, D.W., G.L. Webster and B.S. Blumberg, 1995. Usage and bioassays in Phyllanthus (Euphorbiaceae). IV. Clustering of antiviral uses and other effects. J. Ethnopharmacol., 45: 1-18. http:// www.ncbi.nlm.nih.gov/pubmed/7739222.

8. Paranjape, P., 2001. Indian Medicinal Plants: Forgotten Healers. Chaukhamba Sanskrit Pratisthan, Delhi, $\quad 315$. http://books.google.com.pk/books?id=4wlGQAACAAJ\&dq=Indian+Medicinal+Plants:+ Forgotten+Healers 
9. Lin, T.J., C.C. Su, C.K. Lan, D.D. Jiang, J.L, Tsai and M.S. Tsai, 2003. Acute poisonings with Breynia officinalis-an outbreak of hepatotoxicity. J. Toxicol. Clin. Toxicol., 41: 591-594. http://www.ncbi.nlm.nih.gov/pubmed/14514003

10. Tasaduq, S.A., K. Singh, S. Sethi, S.C. Sharma, K.L. Bedi, J. Singh, B.S. Jaggi and R.K. Johri, 2003. Hepatocurative and antioxidant profile of HP-1, a polyherbal phytomedicine. Hum. Exp. Toxicol., 22: 639-45. http://www.ncbi.nlm.nih.gov/pubmed/14992325

11. Jagetia, G.C. and M.S. Baliga, 2004. The evaluation of nitric oxide scavenging activity of certain Indian medicinal plants in vitro: A preliminary study. J. Med. Food, 7: 343-8. http://www.ncbi.nlm.nih.gov/pubmed/15383230

12. Tona, L., N.P. Ngimbi, M. Tsakala, K. Mesia and K. Cimanga et al., 1999. Antimalarial activity of 20 crude extracts from nine African medicinal plants used in Kinshasa, Congo. J. Ethnopharmacol., $\quad$ 68: 193-203. http://www.ncbi.nlm.nih.gov/pubmed/10624878

13. Tona, L., K. Mesia, N.P. Ngimbi, B. Chrimwami and A. Okond'Ahoka et al., 2001. In vivo antimalarial activity of Cassia occidentalis, Morinda morindoides and Phyllanthus niruri. Ann. Trop. Med. Parasitol., 95: 47-57. http://www.ncbi.nlm.nih.gov/pubmed/11235553

14. Cimanga, R.K., L. Tona, N. Luyindula, K. Mesia and M. Lusakibanza et al., 2004. In vitro antiplasmodial activity of callus culture extracts and fractions from fresh apical stems of Phyllanthus niruri L. (Euphorbiaceae): Part 2. J. Ethnopharmacol., $\quad 95$ : 399-404. http://www.ncbi.nlm.nih.gov/pubmed/15507366

15. Tona, L., R.K., Cimanga, K. Mesia and C.T. Musuamba et al., 2004. In vitro antiplasmodial activity of extracts and fractions from seven medicinal plants used in the Democratic Republic of Congo. J. Ethnopharmacol., 93: 27-32. http://www.ncbi.nlm.nih.gov/pubmed/15182900

16. Subeki, S., H. Matsuura, K. Takahashi, M. Yamasaki and O. Yamato et al., 2005. Anti-babesial and antiplasmodial compounds from Phyllanthus niruri. J. Nat. $\quad$ Prod., 68: 537-9. http://www.ncbi.nlm.nih.gov/pubmed/15844943

17. Mustofa, E.N., Sholikhah and S. Wahyuono, 2007. In vitro and in vivo antiplasmodial activity and cytotoxicity of extracts of Phyllanthus niruri L. herbs traditionally used to treat malaria in Indonesia. Southeast Asian J. Trop. Med. Public Health,38:609-15. http://www.ncbi.nlm.nih.gov/pubmed/17882995
18. Murugaiyah, V., K.L. Chan, 2006. Antihyperuricemic lignans from the leaves of Phyllanthus niruri. Planta Med., 72: 1262-7. http://www.ncbi.nlm.nih.gov/pubmed/16953466

19. Santos, A.R., V.C. Filho, R.A. Yunes and J.B. Calixto, 1995. Analysis of the mechanisms underlying the antinociceptive effect of the extracts of plants from the genus Phyllanthus. Gen. Pharmacol., 26: 1499-1506. http://www.ncbi.nlm.nih.gov/pubmed/8690236

20. Santos, A.R., V.C. Filho, R. Niero, A.M. Viana and F.N. Moreno et al., 1994. Analgesic effects of callus culture extracts from selected species of Phyllanthus in mice. J. Pharm. Pharmacol., 46: 755-759.

http://www.ncbi.nlm.nih.gov/pubmed/7837046

21. Ramakrishnan, P.N., R. Murugesan, S. Palanichamy, 1982. Oral hypoglycaemic effect of Phyllanthus niruri leaves. Indian J. Pharm. Sci., 44: 10-12. http://indianmedicine.eldoc.ub.rug.nl/root/R/95931 $/$ ?pFullItemRecord $=\mathrm{ON}$

22. Chatterjee, M. and P.C. Sil, 2006. Hepatoprotective effect of aqueous extract of Phyllanthus niruri on nimesulide-induced oxidative stress in vivo. Indian J. Biochem. Biophys., 43: 299-305. http://www.ncbi.nlm.nih.gov/pubmed/17133737

23. Bhattacharjee, R. and P.C. Sil, 2006. The Protein Fraction of Phyllanthus niruri plays a protective role against acetaminophen induced hepatic disorder via its antioxidant properties. Phytother. Res., 20: 595-601. http://www.ncbi.nlm.nih.gov/pubmed/16718736

24. Chatterjee, M., K. Sarkar and P.C. Sil, 2006. Herbal (Phyllanthus niruri) protein isolate protects liver from nimesulide induced oxidative stress. Pathophysiology, 13: 95-102. http://www.ncbi.nlm.nih.gov/pubmed/16542828

25. Sarkar, M.K. and P.C. Sil, 2007. Hepatocytes are protected by herb Phyllanthus niruri protein isolate against thioacetamide toxicity. Pathophysiology, 14: 113-20. DOI: 10.1016/j.pathophys.2007.08.001

26. Bhattacharjee, R. and P.C. Sil, 2007. Protein isolate from the herb, Phyllanthus niruri L. (Euphorbiaceae), plays hepatoprotective role against carbon tetrachloride induced liver damage via its antioxidant properties. Food Chem. Toxicol., 45: 817-26. http://www.ncbi.nlm.nih.gov/pubmed/17175085

27. Manjrekar, A.P., V. Jisha, P.P. Bag, B. Adhikary, M.M. Pai, A. Hegde and M. Nandini, 2008. Effect of Phyllanthus niruri Linn. treatment on liver, kidney and testes in $\mathrm{CCl} 4$ induced hepatotoxic rats. Indian J. Exp. Biol., 46: 514-20. http://www.ncbi.nlm.nih.gov/pubmed/18807755 
28. Khanna, A.K., F. Rizvi and R. Chander, 2002. Lipid lowering activity of Phyllanthus niruri in hyperlipemic rats. J. Ethnopharmacol., 82: 19-22. http://www.ncbi.nlm.nih.gov/pubmed/12169400

29. Shakil, N.A., J. Pankaj, R.K. Kumar, Pandey and D.B. Saxena, 2008. Nematicidal prenylated flavanones from Phyllanthus niruri. Phytochemistry, 69: 759-64. DOI: 10.1016/j.phytochem.2007.08.024

30. Iizuka, T., M. Nagai, A. Taniguchi, H. Moriyama and K. Hoshi, 2007. Inhibitory effects of methyl brevifolincarboxylate isolated from Phyllanthus niruri L. on platelet aggregation. Biol. Pharm. Bull., 30: 382-384.

http://www.ncbi.nlm.nih.gov/pubmed/17268086

31. Kieley, S., R. Dwivedi and M. Monga, 2008. Ayurvedic medicine and renal calculi. J. Endourol., 22: 1613-1616. http://www.ncbi.nlm.nih.gov/pubmed/18620498

32. Ogata, T., H. Higuchi, S. Mochida, H. Matsumoto, A. Kato, T. Endo, A. Kaji and H. Kaji, 1992. HIV1 reverse transcriptase inhibitor from Phyllanthus niruri. AIDS Res. Hum. Retrovir., 8: 1937-44. http://www.ncbi.nlm.nih.gov/pubmed/1283310

33. Naik, A.D. and A.R. Juvekar, 2003. Effects of alkaloidal extract of Phyllanthus niruri on HIV replication. Indian J. Med. Sci., 57: 387-393. http://www.ncbi.nlm.nih.gov/pubmed/14515028?d opt $=$ Abstract

34. Qian-Cutrone, J., S. Huang, J. Trimble, H. Li, P.F. Lin, M. Alam, S.E. Klohr and K.F. Kadow, 1996. Niruriside, a new HIV REV/RRE binding inhibitor from Phyllanthus niruri. J Nat. Prod., 59: 196-199. http:// www.ncbi.nlm.nih.gov/pubmed/8991954

35. Campos, A.H. and N. Schor, 1999. Phyllanthus niruri inhibits calcium oxalate endocytosis by renal tubular cells: Its role in urolithiasis. Nephron, 81: 393-397.

http://www.ncbi.nlm.nih.gov/pubmed/10095174

36. Freitas, A.M., N. Schor and M.A. Boim, 2002. The effect of Phyllanthus niruri on urinary inhibitors of calcium oxalate crystallization and other factors associated with renal stone formation. BJU. Int., 89: 829-34.

http://www.ncbi.nlm.nih.gov/pubmed/12010223

37. Barros, M.E., N. Schor and M.A. Boim, 2003. Effects of an aqueous extract from Phyllantus niruri on calcium oxalate crystallization in vitro. Urol. Res., 30: 374-379. http://www.ncbi.nlm.nih.gov/pubmed/12599017

38. Nishiura, J.L., A.H. Campos, M.A. Boim, I.P. Heilberg and N. Schor, 2004. Phyllanthus niruri normalizes elevated urinary calcium levels in Calcium Stone Forming (CSF) patients. Urol. Res., 32: 362-366. http://www.ncbi.nlm.nih.gov/pubmed/15221244
39. Micali, S., M.C. Sighinolfi, A. Celia, S. De Stefani, M. Grande, A.F. Cicero and G. Bianchi, 2006. Can Phyllanthus niruri affect the efficacy of extracorporeal shock wave lithotripsy for renal stones? A randomized, prospective, long-term study. J. Urol., 176: 1020-1022. http://www.ncbi.nlm.nih.gov/pubmed/16890682

40. Barros, M.E., R. Lima, L.P. Mercuri, J.R. Matos, N. Schor and M.A. Boim, 2006. Effect of extract of Phyllanthus niruri on crystal deposition in experimental urolithiasis, Urol. Res., 34: 351-357. http://www.ncbi.nlm.nih.gov/pubmed/16896689

41. Mulchandani, N.B. and S.A. Hassarajani, 1984. 4Methoxy-nor-Securinine, a New Alkaloid from Phyllanthus niruri. Planta Med., 50: 104-105. http://www.ncbi.nlm.nih.gov/pubmed/17340265

42. Mellinger, C.G., T.R. Cipriani, G.R. Noleto, E.R. Carbonero and M.B. Oliveira et al., 2008. Chemical and immunological modifications of an arabinogalactan present in tea preparations of Phyllanthus niruri after treatment with gastric fluid. Int. J. Biol. Macromol., 43: 115-120. http://www.ncbi.nlm.nih.gov/pubmed/18501421

43. Shimizu M, S. Horie, S. Terashima, H. Ueno and T. Hayashi et al., 1989. Studies on aldose reductase inhibitors from natural products. II. Active components of a Paraguayan crude drug "Paraparai mí," Phyllanthus niruri. Chem. Pharm. Bull. (Tokyo), 37: 2531-2532. http://www.ncbi.nlm.nih.gov/pubmed/2514047

44. Elfahmi, S. Batterman, A. Koulman, T. Hackl and R. Bos et al., 2006. Lignans from cell suspension cultures of Phyllanthus niruri, an Indonesian medicinal plant. J. Nat. Prod., 69: 55-58. http://www.ncbi.nlm.nih.gov/pubmed/16441068

45. Murugaiyah, V and K.L. Chan, 2007. Determination of four lignans in Phyllanthus niruri L. by a simple high-performance liquid chromatography method with fluorescence detection. J. Chromatogr. A., 1154: 198-204. http://www.ncbi.nlm.nih.gov/pubmed/17418855

46. Harborne, J.B.C., 1973. Phytochemical Methods. Chapman and Hall, London, ISBN: 0412105403 pp: 278

47. Trease, G.E. and W.C. Evans, 1983. Drugs of Biological Origin. In: Pharmacognosy. 12th Edn., Balliere Tindall, United Kingdom, ISBN: 0702010073, pp: 821.

48. Morton, J.J.P. and M.H. Malone, 1972. Evaluation of vulnerary activity by an open procedure in rats. Arch. Int. Pharmacodyn., 117-126. http://www.ncbi.nlm.nih.gov/pubmed/5059357 
49. Aguwa, C.N. and G.C. Mittal, 1981. Study of antiulcer activity of aqueous extract of leaves of Pyrenacantha standtii (Family Icacinaceae) using various models of experimental gastric ulcer in rats. Eur. J. Pharmacol., 74: 215-219. http://www.ncbi.nlm.nih.gov/pubmed/7327202

50. Cashin, C.H., W. Dawson and E.A. Kitchen, 1979. The pharmacology of benoxaprofen (2-4chlorophenyl-methyl-5-benzoxazole acetic acid) LRC.L3694, a new compound with antiinflammatory activity apparently unrelated to inhibition of prostaglandin synthetase. J. Pharm. Pharmacol., $\quad$ 29: 330-336. http://www.ncbi.nlm.nih.gov/pubmed/18568

51. Mizui, T. and M. Douteuchi, 1983. Effect of polyamines on acidified ethanol induced gastric lesions in rats. Jap. J. Pharmacol., 33: 939-945. http:// www.ncbi.nlm.nih.gov/pubmed/6580476

52. Nagura, M., 1972. Effect of psychotropic drugs on cathecolamines in brain and adrenal medulla of rats under stress producing peptic ulcers. Jap. J. Pharmacol., $\quad 22$ : 545-549. http://www.ncbi.nlm.nih.gov/pubmed/4539507.

53. Goulart, Y.C.F., V.R. Sela, S. Obici, J.V.C. Martins, F. Otobone, D.A. Cortez, E.A. Audi, 2005. Evaluation of gastric anti-ulcer activity in a hydroethanolic extract from Kielmeyera coriacea. Braz. Arch. of Biol. and Technol., 48: 211-216. http://www.scielo.br/pdf/babt/v48n2/23760.pdf

54. Ross, J.S. and J.W.K. Wilson, 1970. Foundation of Nursing and First Aid. 5th Edn., Churchill Livingstone, Edinburgh, ISBN: 0443007357, pp: 304.

55. Whaley, K. and A.D. Burt, 1996. Inflammation, Healing and Repair. In: Muir's Textbook of Pathology, MacSween, R.M.N. and K. Whaley (Eds.). 13th Edn., Arnold, London ISBN: 0340569573, pp: 112-165.

56. Cotran, R.S., V. Kumar, S.L. Robbins and F.J. Schoen, 1994. Inflammation and Repair. In: Robbins Pathologic Basis of Disease, 5th Edn, W.B. Saunders Company, Pennsylvania, ISBN: 0-72165032-5, pp: 51-92.

57. Mohan, H., 2005. Inflammation and Healing. In: Textbook of Pathology, 5th Edn., Jaypee Brothers, New Delhi, ISBN: 81-8061-368-2, pp: 133-179.

58. Bairy, K.L. and C.M. Rao, 2001. Wound healing profiles of Ginkgo biloba. J. Nat. Rem., 1/1: 25-27. www.jnronline.comlbody_volume.1.html

59. Azad, S., 2002. Essentials of Surgery. Paras Medical Publications, Hyderabad, ISBN: 8181911180, pp: 1.
60. Swamy, K.H., V. Krishna, K. Shankarmurthy, A.B. Rahiman and K.L. Mankani et al., 2007. Wound healing activity of embelin isolated from the ethanol extract of leaves of Embelia ribes Burm. J. Ethnopharmacol., 109: 529-534. DOI: 10.1016/j.jep.2006.09.003

61. Harish, B.G., V. Krishna, H.S. Kumar, K.B. Ahamed, R. Sharath and K.H. Swamy, 2008. Wound healing activity and docking of glycogen-synthase-kinase3 - $\beta$-protein with isolated triterpenoid lupeol in rats. Phytomedicine, 15: 763-767. DOI: 10.1016/j.phymed.2007.11.017

62. Vane, J.R., 1971. Inhibition of prostaglandin synthesis as a mechanism of action of aspirin-like drugs. Nat. N. Biol., 231: 232-235. http://www.ncbi.nlm.nih.gov/pubmed/5284360

63. Soll, A.H., W.M. Weinstein, J. Kurata and D. McCarthy, 1991. Non-steroidal anti-inflammatory drugs and peptic ulcer disease. Ann. Intern. Med., 114: 307-319. http://www.ncbi.nlm.nih.gov/pubmed/1987878.

64. Ferreira, S.J. and J.R. Vane, 1974. New aspects of the mode of actions of NSAIDs. Ann. Rev. Pharmacol., 14: 57-70.

65. Garner, A., G. Flemstrom and J.R. Heylings, 1979. Effects of anti-inflammatory agents and prostaglandins on acid and bicarbonate secretions in the amphibian isolated gastric mucosa. Gastroenterology, 77: 451-457. http://www.ncbi.nlm.nih.gov/pubmed/313351

66. Menguy, R. and L. Desbaillets, 1967. Role of inhibition of gastric mucous secretion in the phenomenon of gastric mucosal injury by indomethacin. Am. J. Dig. Dis., 12: 862-866. http://www.ncbi.nlm.nih.gov/pubmed/6039569

67. Koo, M.W.L., C.W. Ogle and C.H. Cho, 1986. Effect of verapamil, carbenoxolone and $\mathrm{N}$ acetylcysteine on gastric wall mucus and ulceration in stressed rats. Pharmacology, 32: 236-334. http://www.ncbi.nlm.nih.gov/pubmed/3725888

68. Marhuenda, E., M.J. Martin and C.A.D. La Lastra, 1993. Anti-ulcerogenic activity of aescine in different experimental models. Phytother. Res., 7: 13-16. http://cat.inist.fr/?aModele=afficheN\&cpsidt $=4556332$

69. Galvin, G.B. and S. Szabo, 1992. Experimental gastric mucosal injury: Laboratory models reveal mechanisms of pathogenesis and new therapeutic strategy. Federat. Am. Soc. Exp. Biol. J., 6: 825-831. http://cat.inist.fr/?aModele $=$ afficheN\&cpsidt $=11350134$

70. Dreyling, K.W., K. Lange, B.A. Peskar and B.M. Peskar, 1986. Release of leukotrienes by rat and human gastric mucosa and its pharmacological modification. Br. J. Pharmacol. Proc. Suppl., 88: 236. PMCID: PMC1916919. 
71. Peskar, B.M., K. Lange, U. Hoppe and B.A. Peskar, 1986. Ethanol stimulates formation of leukotriene $\mathrm{C}_{4}$ in rat gastric mucosa. Prostaglandins, 31: 283-293. http://www.ncbi.nlm.nih.gov/pubmed/3515429

72. Cho, C.H., C.W. Ogle and E.L. Sevila, 1987. The protective effect of sulphasalazine against ethanolinduced gastric damage in rats. Br. J. Pharmacol., 92: 31-37. http://www.ncbi.nlm.nih.gov/pubmed/2889494

73. Mizui, T. and M. Doteuchi, 1986. Lipid peroxidation a possible role in gastric damage induced by ethanol in rats. Life Sci., 38: 2163-2167. http://www.ncbi.nlm.nih.gov/pubmed/3458990

74. Pihan, G., C, Regillo and S. Szabo, 1987. Free radicals and lipid peroxidation in ethanol-or aspirin-induced gastric mucosal injury. Dig. Dis. Sci., 32: 1395-1401. http://www.ncbi.nlm.nih.gov/pubmed/3691277

75. Robert, A., J.E. Nezamis, C. Lancaster and A.J. Hanchar, 1979. Cytoprotection by prostaglandins in rats. Prevention of gastric necrosis produced by alcohol, $\mathrm{HCl}, \mathrm{NaOH}$, hypertonic $\mathrm{Nacl}$ and thermal injury. Gastroenterology, 77: 433-443. http://www.cababstractsplus.org/abstracts/Abstract. aspx?AcNo=19791495041

76. Murakami, M., S.K. Lam, M. Inada and T. Miyake, 1985. Pathophysiological and pathogenesis of acute gastric mucosal lesions after hypothermicrestraint stress in rats. Gastroenterology, 88: 660-665. http://www.ncbi.nlm.nih.gov/pubmed/3967803
77. Okubo, T., Y. Watanabe, T. Kidokoro, K. Ishihara and K. Hotta, 1986. Correlation of quantitative changes of gastric mucosal glycoproteins in restraint and water immersion stress in rats. Jap. J. Gastroenterol., $\quad$ 83: $1111-1116$. http://www.ncbi.nlm.nih.gov/pubmed/3761679

78. Hase, T. and B.J. Moss, 1973. Microvascular changes of gastric mucosa in development of stress ulcers in the rats. Gastroenterology, 65: 224-234. http://www.ncbi.nlm.nih.gov/pubmed/4720026

79. Cho, C.H., C.W. Ogle and S. Dai, 1976. Acute gastric ulcer formation in response to Electrical Vagal stimulation in rats. Eur. J. Pharmacy., 35: 215-219. http://www.ncbi.nlm.nih.gov/pubmed/1253823

80. Garrick, T., S. Buack and P. Bass, 1986. Gastric motility is a major factor in cold restraint induced lesion formation in rats. Am. J. Physiol., 250: G191-199. http://www.ncbi.nlm.nih.gov/pubmed/3953798

81. Rachchh, M.A. and S.M. Jain, 2008. Gastroprotective effect of Benincasa hispida fruit extract. Ind. J. Pharmacol. 40: 271-275. http://indianmedicine.eldoc.ub.rug.nl/root/R2/312r/ ?pFullItemRecord $=\mathrm{ON}$ 